\title{
Contribution of Sufism to the Development of Moderate Islam in Nusantara
}

\author{
M. AFIF ANSHORI*, ZAENUDDIN HUDI PRASOJO \& LAILIAL MUHTIFAH'1
}

\begin{abstract}
This article analyzes the relationship between Sufism (mystical Islam) and the making of moderate Islam in Nusantara, a region that historically has been covered by various Muslim-majority populations in Southeast Asia, especially Indonesia. This focus is important for two reasons. First, Islam was first introduced to this region through the hands of Sufi preachers when Sufism was the the-dominant feature of Islam. Second, Islam has been practiced peacefully in this region for centuries through an adaptation with mystical practices of the local beliefs. Thus, the main question of this article is aimed at exploring the ways in which Sufism has contributed to the development of moderate Islam in Nusantara. In doing so, two different approaches are employed: the orthopraxic and historical approach and the phenomenological approach. While the former is especially employed to examine the historical introduction of Sufism into Nusantara, the latter is to analyze the essential teachings of Sufism, which are deemed flexible and inclusive towards cultural diversity. This study concludes that the development of moderate Islam in Nusantara cannot be separated from the century-long contribution of Sufism, the implication of which has created fundamental structures for harmonization of religious lives in Nusantara.
\end{abstract}

Keywords: Sufism, Moderate Islam, Religious Harmony, Nusantara

At the turn of the $3^{\text {rd }}$ millennium, harmonization of religious life in this so-called postmodern society has faced serious challenges, evidenced by the rising conflicts between religious believers (Ismardi \& Arisman, 2014), such as in Yugoslavia (Frusetta, 2014) in the Middle Eastern region (Lai, 2006). Initially triggered by social, economic, and/or political problems, these conflicts were considered a "holy war" due gleaning justifications from religious texts. This is arguably possible because of the difference in approaches of understanding Islam ranging from the moderate to the puritan interpretations (el-Fadl, 2005).

'Nusantara' has historically referred to Muslim-populated areas in Southeast Asia. Muslims have for centuries lived peacefully in these areas with adherents of other religions, such as Christianity, Catholicism, Hindu, Buddha, and Confucianism. Despite the rise of horizontal conflicts in the last few decades in Nusantara, the conflicts were sporadic and relatively resolved immediately. This fact has triggered a number of questions this paper wants to examine, including why has Islam

${ }^{1}$ M. Afif Anshori, Ph. D.* (Correnponding Author), Assoc. Professor, Islamic State University of Raden Intan Lampung, Jl. H. Endro Suratmin - Sukarame, BANDAR LAMPUNG, Indonesia. Email: afifansori@radenintan.ac.id; Zaenuddin Hudi Prasojo, Ph. D., Assoc. Professor, Institut Agama Islam Negeri (IAIN) Pontianak, Jl. Letjend Suprapto, Nomor 19, KOTA PONTIANAK, Kalimantan Barat, Indonesia. Email: zaestain@yahoo.com; Lailial Muhtifah, Ph. D., Assoc. Professor, Institut Agama Islam Negeri (IAIN) Pontianak, Jl. Letjend Suprapto, Nomor 19, KOTA PONTIANAK, Kalimantan Barat, Indonesia. Email: laililal.muhtifah23@gmail.com.

https://doi.org/10.24035/ijit.19.2021. 194 
in Nusantara been able to thrive harmoniously with other religions and local beliefs embraced by the region's multicultural societies? And speficially if there is any significant role played out by Sufism, (considering its historical presence and practices across the Nusantara regions) to the development of the inclusive Islam (or moderate Islam) in Nusantara?

\section{Research Method}

Object materials of this study focus on Sufism, regarded as the essence of Islamic teachings (alTaftazani, 1983; Hamka, 1996; Nasr, 1996; Siroj, 2009; Syukur, 1999) and employs a number of approaches. The first is the orthopraxic approach, or seeing Islam as a social phenomenon (Bakri, 2014; Elmansyah at.al., 2019; Ahmadi, 2017). The second is the historical approach, or studying Islam from the perspective of historical sciences (Kamaruzzaman, 2002). The historical approach is used to examine the history of the development of Islam in Nusantara. The third is phenomenology, used to examine the inner experience of individuals' life, manifested as an experience of a phenomenon or an exact appearance, commonly called consciousness (Campbel \& Hardiman, 1994; Hakiki, 2018).

\section{Literature Review}

The term 'moderate', along with its Arabic equivalent of wasata, is widely used in public, especially among scholars, state leaders, Islamic governments, and religious figures. It has various meanings (Hornby, 1983), such as average in amount and intensity and doing things within the limits that are not excessive. Similarly, the Arabic word wasata also refers to different meanings, including being fair, humble, and moderate. Sometimes, it is related to a balanced position between two ends. Thus, in Islamic epistemology, the concept of wasatiyat refers to moderate people (Hanapi, 2014; Kasdi, 2019; Ahmadi, 2017).

Among Muslim scholars, the term "moderate Islam", popularly translated into "ummatan wasatan", has four different related features (Mazuki et al., 2013). They are, tawassut, or a middle position between two opposite sides; mulazamatu al-adli wa al-i'tidal, or holding a just and balanced attitude; afdhaliyat/khairiyat, or taking a side that does not negate the opposing opinions; and istiqâmat 'alâ al-tarîq, or being consistent in the straight path. All of these meanings are strengthened by the Qur'an (2:143).

For all Muslims, the Qur'an and Hadith are the two main references of religious knowledge. Yet, historically, the actual practice of lived Islam varies from time to time, and from one to another society. Muslims around the world have long been divided into various groups, each of which is distinguished by an individual's own religious practices and rituals. Such difference, however, should be seen as an order of nature (sunnatullah) desired by God (Shihab, 2007; Alam, 2016).

In practice, however, the term moderatism is not easy to define, due to its highly contested nature, both within the internal circles of Muslims, and the non-Muslim externals (Esposito, 2005). It is understood differently by many people, depending on the subjects and the contexts in which they are approached and understood.

Western thinkers have set some criteria for a definition of a moderate Muslim. According to Daniel Pipes, they include recognition of equal civil rights between Muslims and non-Muslims, a right of religious conversion for Muslims, an inter-religious marriage between a Muslim woman with a non-Muslim man, loyalty to the laws of a non-Muslim government; and taking side with the secular law when it is opposed to the Islamic culture (Pipes, 2005). According to Esposito and Mogahed, the difference between the radical and the moderate Muslims is that while the latter tends to feel that the West is threatening them and trying to control their lives, the former shows their confidence to build a relationship with the West, especially through and in the field of economic development (Esposito \& Mogahed, 2006).

https://doi.org/10.24035/ijit.19.2021.194 
Yet, researcher of Islam Robert Spencer (as cited in Zakarya, 2017) has argued to be considered a moderate Muslim one must reject the application of Islamic law to non-Muslims, the replacement of a secular state with the Islamic one, the supremacy of Islam over other religions, the death punishment of a Muslim convert (apostate), and the prohibition of interfaith marriage. Obviously, unlike the radical Muslims who are viewed as trapped in the glorious past of Islam, and thus threatening to the secular body of Western civilization, moderate Muslims are perceived by Western thinkers as compatible with almost all societies around the world (Auster, 2005).

Islamic moderatism is based on a clear and definite doctrine, which consists of a mixture between reason and revelation, between dimensions of physicality and spiritualism, and between justice and prosperity. This has rendered Islamic moderatism different from moderatism of other religions and cultures. Moderatism in the Western world, for example, is not the same as that in Islam, as the latter is mainly based on rationality, at the detriment of revelation. In this regard, Islamic moderatism, which combines rationality and divinity, is often regarded as more solid than that of Western civilization.

In Indonesia, the notion of moderate Islam, as I will illustrate later, is not only widely practiced, but also has century-long historical roots. It is Nahdlatul Ulama and Muhammadiyah, the two biggest organized forms of Islam in Indonesia, that have for many decades upheld an interpretation of Islamic teachings that is inclusive, adaptive, and tolerant to local culture and customs. The most relevant example is their acceptance of Pancasila (Five Pillars), instead of Islam, as the ideological foundation of the 'non-Islamic' state of Indonesia (Murod, 2011; Jubba, 2019).

Yet, there has been a rise of radical movements introducing an extreme and violent-laden form of Islam in Indonesia, especially since the Reform era (after the resignation of Suharto in 1998). While they are seen as a new phenomenon and are not originated from the Islamic Indonesian circus, their rise in the country should be seen as a challenge to moderate Islam (Misrawi, 2010). Moreover, since they have started to penetrate the deep structure of Nahdlatul Ulama and Muhammadiyah, the two latter movements have tested their strength to maintain the moderate character of Indonesian Islam (Nursyam, 2009). In other words, there is a question for all of us about about how to keep moderate Islam the dominant narrative of Islam that is operative in Indonesia, and that Islam is a blessing for all living beings in the universe.

\section{Sufism and the Development of Nusantara Islam}

To understand what Nusantara Islam is, one must believe in both religious and cultural dimensions (Sahal, 2015). These dimensions relate to how Islam is embraced by people living in a certain cultural society. Thus, practiced Islam is not rigid and exclusive, but respecting of other values: hence the compatibility of Islam with other cultural values is also believed in society.

The term Nusantara Islam refers to the Islam historically lived and practiced by the Muslim ummah (community of believers) in regions that now cover Indonesia, Malaysia, Brunei, Pattani (Southern Thailand), and Mindanao (Southern Philippines). Nusantara's geography is described in pre-colonial literature as "the land below the wind", and in Arabic literature since the $16^{\text {th }}$ century as "Bilad al-Jawi" (land of the Jawi people), or "Ashab al-Jawiyyin" and "Jama'at al-Jawiyy" (referring to members of the Jawi community) (Azra, 2015). In this regard, the region of Nusantara Islam can be considered one of the major domains of Islam, in addition to, the Arab continent, Persia/Iran, Turkey, India, Sino Islam, Black Africa, and the Western World. Although holding the same main religious practices and doctrines, Islam in these domains has its own spiritual styles and cultural appearances.

Nusantara Islam as an empirical reality has been developed in the archipelago at least since the $16^{\text {th }}$ century, through the long processes of contextualization, indigenization, and vernacularization of universal teachings of Islam with local Indonesian cultures and beliefs. Yet, ideologically, the term was officially introduced in 2015 by Nahdlatul Ulama, as an alternative interpretation of Islam versus the global society, which has always been dominated by Arab and

https://doi.org/10.24035/ijit.19.2021.194 
Middle Eastern perspectives. Thus, the main feature of Nusantara Islam is its consideration of local culture and customs, especially concerning the formulation of (fiqh) Islamic law (Fachrudin, 2015). It is in this regard that the President of Indonesia, Joko Widodo, has lent his support to Nusantara Islam, which he defined as the form of Islam that is moderate and nicely fits the cultural values of Indonesia (Arifianto, 2017). I argue, the compatibility of Islam with local cultures of Indonesia cannot be separated from the significant role of Sufism, having started since its century-long arrival at the region, which I will explore below.

The introduction of Sufism in Nusantara coincided with the arrival of Islam in the region, which, according to Azra, arguably occurred between the $12^{\text {th }}$ and the $15^{\text {th }}$ century (Azra, 1990). This means the Islamization of Nusantara began when Sufism was the dominant style of thought in the Islamic world, evidenced by the strong influence of prominent Sufi saints and thinkers like Ibn Arabi and Al-Ghazali to the earlier Muslim writers in Nusantara (Bruinessen, 1992). This fact explains why the Islamization process of Nusantara was relatively peaceful. Since the Nusantara people were known as more mystical than rational, when Islam of the mystical style first came to the region, people easily accepted the new religion.

The spread of Islam in Nusantara was a slow and gradual process. It is said the new religion was brought to the region by Sufi preachers and traders during the $12^{\text {th }}$ or $13^{\text {th }}$ century, either through Gujarat in India or directly from the Middle East (Burhanudin \& van Dijk, 2013). Already in the $16^{\text {th }}$ century, Islam replaced Hinduism and Buddhism as the majority religion in Nusantara. The practice of early Islam in Nusantara was part of the Sunni Islam, with strong influences of Sufistic rituals and teachings, and often closely linked to the ritual practices of Javanese and other local religions (Noer, 1973). Their close proximity is evidenced by the highly practiced traditions of pilgrimage to the grave of saints, congregational recitation of dzikr (remembrance of God), and commemoration of the birth of the prophet (mawlid), among Indonesian Muslims (Rosyidi, 2012).

Yet, the arrival of modernist Muslims by the turn of the $21^{\text {st }}$ century, which was followed by the coming of Wahhabi-Salafi teachings from Arabia, changed the landscape of Islam in Nusantara. Scripural and puritan, the modernist Muslims rejected the traditional practices of Islam and denounced them as shirk or bid'a, a practice of syncretism that reduces the sanctity of Islam. This condition led to religious tensions between Nahdlatul Ulama and the modernist Muhammadiyah (Fuad, 2015).

A dramatic change, however, has occurred in the last few decades. The devastation of Muslim-majority Middle Eastern societies due to the unending wars in the Arab World, laden with religious sentiments, have led to a serious religious problem with the emergence of radical Islam (Hefner, 2002). The ultra-conservative Salafi and Wahhabi doctrines sponsored by the Saudi government have dominated the global discourse on Islam (Ammar \& Songhua Xu, 2017). This concern was exacerbated by the emergence of ISIS (Islamic State of Iraq and Syria) in 2013, lustfully staging vicious war crimes in the name of Islam (Fathun, 2016). In Indonesia, several Islamist organizations such as Hizbut Tahrir Indonesia (HTI), Front Pembela Islam (Defender Front of Islam, FPI) (Faiz, 2014), and Partai Keadilan Sejahtera (Justice and Prosperous Party, PKS) have increased their political maneuvers and influences in recent years. As such, they have disturbed the dominance of traditional Islamic institutions, especially the NU. The rise of Islamism is considered threatening the supremacy of Pancasila, the five pillars upon which the ideology of the state of Indonesia is based (Khamdan, 2016).

This has encouraged many moderate Muslim thinkers and leaders in Indonesia to take distance and distinguish themselves from the so-called "Arab Islam", by coining the term Nusantara Islam. Compared to situations in the Middle East, Muslims in Nusantara have lived for ages in peace and harmony with people of different religions. As such, this is believed to have been influenced by the cultural understanding of Islam in Nusantara, which is moderate, inclusive, and tolerant. In addition, support has come from the international community, encouraging Indonesia - as the largest 
Muslim country - to contribute to the progress and development of the Islamic world, by campaigning the Nusantara Islam as an alternative to Saudi Wahhabism (Nurhisam, 2016).

The main characteristics of Nusantara Islam are tawasut (moderate), rahmah (compassion), anti-radicalism, inclusivity, and tolerence (Luthfi, 2016). In relation to local culture, Nusantara Islam uses a sympathetic, cultural approach: it does not destroy and eradicate local culture, but embraces, respects, safeguards, and preserves it. Nusantara Islam also recognizes the significance of Indonesian local culture for the formulation of figh or Islamic jurisprudence.

The notions of Nusantara Islam are locally bred in Islamic boarding schools (pesantren) existing across the archipelago country. The centers are traditional institutions of Islamic learning which give strong emphasis on local and Islamic ethics, such as giving respect to kyai as the pesantren's religious teachers. Islamic learning in a pesantren is distinguished by emphasis on the principle of Islam as 'rahmat li al- 'alamîn" (lit, a mercy for the universe). It is the universal value of Islam that promotes peace, tolerance, mutual respect, and diversity of opinion either among fellow Muslims or non-Muslim others (Karim, 2007).

Soon after the idea of Nusantara Islam was launched to the public by the NU, it received severe opposition from other Muslim groups, especially those who wanted to purify Islam from elements of local culture. HTI, for example, criticized Nusantara Islam as a form of syncretism, damaging not only the perfection of Islam, but also the unity of the people (Helmy, 2011). The modernist Muhammadiyah, known for its rivalry with the traditionalist Muslims, went on to create their own term, the progressive Islam (Islam Berkemajuan), and condemned careless public use of the term which may oppress other Islamic groups having different understandings of Islam (Ali, 2015).

\section{Contribution of Sufism}

As stated earlier, the smooth and peaceful process of Islamization in Nusantara has had much to do with Sufism, known for its flexible, accommodating, moderate, and tolerant nature. The inclusiveness of mystical teachings of Islam, which are more concerned with the "substance" than "symbols" of religion, has made the Sufism-based approach of proselytizing Islam more appealing than that of the shari'a-centered approach.

Sufism is also known as esoteric Islam. The term esoteric comes from esoteris (adj), which means, "intended only for those who are initiated..." (Hornby, 1983: 291), or "only known and understood by certain people"(John M. Echols \& Shadily, 1996: 218). Esoteric things often relate to aspects of the heart, which are opposed to the outward dimensions of shari'a and the material world.

In Islam, the notion of esotericism has long become a polemic, the beginning of which parallel the history of Islam itself. For a long time, many scholars have differentiated esoteric Islam (mysticalinclined Islam) from exoteric Islam (sharia-inclined Islam), arguing that Islamic esotericism is a synthesis of different 'other thoughts' (Sugiharto, 1996), or an adaptation of non-Islamic teachings (al-Taftazani, 1983). Yet, the esoteric Islam of Sufism is not without reference from the Qur'an and Hadith (Nasr, 1996).

It is the focus of Sufism on esoteric Islam that has made it flexible and tolerant, thus rendering it different from the legal-centered understanding of Islam, which tends to refer to legal texts of Islam as religious guidance. In contrast, Sufi saints have closely linked their interpretation of Islamic teachings with religious customs and cultural values of the local people, sometimes resulting in ritual practices not known during the early periods of Islam. In other words, Sufism pays more emphasis on the inward dimension of the religion and its relation with the virtues of the local culture. Thus, it is not surprising that rituals such slametan (religious offering) and tahlilan (recitation of dzikr for the dead), marhabanan (recitation of prayers to the Prophet), similar to ritual practices of local beliefs in Indonesia, are widely practiced among Indonesian traditionalist Muslims.

Sufism is the spirit of Islam, because all Islamic laws are based on ethics and morality. In this regard, Hamka calls it a modern Sufism, or "leaving behind the bad behavior for embracing the good 
behavior" (Hamka, 1996). This means purifying the soul, educating the mind, avoiding material wealth, and restraining from sexual desire, in order to achieve self-prosperity.

Doctrines and teachings of Sufism are practiced in accordance with humans' social problems and realities. Thus, the aim of this practice is not only to achieve individual tranquility, peace, and piety, but also social harmony of the community. It does not only concern 'ascending to heaven in isolation' but also tries to create a heaven for all people (Muhayya, 2001).

With regard to its purpose, Sufism is divided into two kinds (Syukur, 1999). First, Sufism is oriented toward self-transformation of the Sufi individuals. Here, the teachings and ritual practices of Sufism are aimed to transform the soul and behavior of the Sufi travelers (salik). Second, Sufism is oriented toward social transformation, which started from the smallest circle of the Sufi travelers, to their families, and eventually to their bigger communities.

Sufism is not only concerned with the vertical dimensions of a ritual, but also its social dimensions. It carries out a mission of social transformation, such as providing an alternative solution to social problems in society. The social crises that plague Indonesia, for example, are not only limited to monetary, economic, and political issues, but also moral and spiritual crises (Siroj, 2009). This is where the significance of the esoteric dimension of the teachings of Islam lies. The obligation among Muslims to believe in God, the doomsday, and the good virtue (pious deeds), all are a sign that the spiritual and social dimensions of Islam are just part of humans' historical realities.

The notion of social piety emphasized by Sufism is inclusive and moderate, as it is applied to human beings of all backgrounds: religion, ethnicity, race, and social class. The inclusiveness of moderate Sufism is increasingly apparent when it is in contact with other religions, as it focuses not on the difference between religions, but their similarity. In this way, the difference that exists among religions is seen as a matter of superficial appearance; while esoterically, all religions are considered similar.

It is the inclusiveness and moderatism of Sufism that has been crucial to the peaceful process of Islamization in Nusantara (Shihab, 2001). The Sufi preachers, among the first to introduce Islam in the region, were characterized by their sociability with low-class, ordinary people, and by their exemplary behavior, symbolizing the peak of their faith and piety, manifested in the form of, among others, charitable services and brotherhood solidarity. Such exemplary behavior has aroused sympathy from many people, piquing interest in the new religion and eventually embracing Islam. Were it not for the Mystical Islam, the acculturation process of Islam with local culture in Nusantara would have been much more difficult (Amrizal, 2018).

The significance of Sufism to the Islamization of Nusantara is also evidenced by the role of tarekat (Sufi order) groups. Practicing a moderate way of living, Sufi orders have carefully used culture as a medium of their dakwah. This way, leaders of a Sufi order are demanded to be creative, productive, and adaptive in order to create a cultural product that is attractive to their prospective members. Likewise, they are required to modify and transform a local culture into a cultural form that is imbued with Islamic values. Pesantrens are the case in point. They are a modification of a Hindu-Buddhist boarding-house-based education, which has strong connections with the zawiyyah 'learning' system among the Sufi students. It is the ability of the Sufi teachers to introduce Islam with an adaptive cultural approach, that has enabled Islam to take a deep root in many new places(Gibb, 1945).

The biggest contribution of Sufism to Nusantara, however, is the creation of a religious life that is harmonious, peaceful, and tranquil. In a society of people with various religious backgrounds, inter-religious conflict is seen as a constant threat. Observed from the perspective of a construction theory, inter-religious harmony can be developed through various factors, such as effective channels of communication and effective systems of arbitration (Affandi, 2012). Yet, this paper argues religious tolerance is also important to make a harmonious life among people of different religious backgrounds. 
Tolerance is an embodiment of faith embedded in a society's everyday life. It can be achieved by religious members through the making of a social life that enhances mutual understanding and sympathy. Tolerance leads to both inclusiveness and willingness to accept diversity, be it ethnicity, language, culture, or religion. It is through tolerance that dialogue between religious groups becomes possible (Tabik, 2016). The case in point is the graves of the two earliest Muslim preachers in Bali, Raden Amangkuningrat and Ratu Ayu Anak Agung Rai, which are now functioned not only as a temple for the Hindu Balinese people, but also as a destination of religious tourism among Muslim visitors to the city (G.A et al., 2015). The harmonious interaction between the Hindus and Muslims regarding the graves could be hardly possible with the absence of religious tolerance among them.

Obviously, religion has a sociological function of uniting people of similar religious beliefs (Affandi, 2012). Yet, this function will face some difficulty when it comes to adherents of different religious beliefs. In this regard, the context of social relations that occurs between people of different religious conviction is crucial: and it is in Sufism that the meeting and adhesive point between various religions and cultures can unite, hence the harmonization of a religious life.

This work suggests that, with the support of an analysis of appropriate data, the moderatism of Nusantara Islam could produce a sense of order, peace, and stability in a society of various religious adherents such as the country Indonesia where Muslims live side by side peacefully with believers of other religions. Sufism, which emphasizes notions of noble virtues and morality (alakhlâq al-karimah), has greatly contributed to the making of religious harmony in Indonesia. This article concludes that central to the production of such religious harmony is the act of equalizing what is similar, and respecting what is different.

\section{References}

Affandi, N. 2012. Harmoni dalam keragaman: studi analisis tentang konstruksi perdamaian antar umat beragama. Lentera. 14(1): 71-84.

Ahmadi, R. 2017. Socio-Sufism of Orang Maiyah: Toward Human Sovereignty in Togetherness. AlAlbab, 6(2), 179 - 196. doi:https://doi.org/10.24260/alalbab.v6i2.671.

Alam, M. 2016. Harmony in Religious and Cultural Diversity: Case Study of Sungai Penuh City Society. Al-Albab, 5(2), 265 - 280. doi:https://doi.org/10.24260/alalbab.v5i2.554.

al-Taftazani, A. al-Wafa' al-Ghunaimi. 1983. Madkhal ila al-Tasawwuf al-Islamy. Kairo, Dar alTsaqafah li al-Nasyr wa al-Tawzi'.

Ali, M. 2015. The Muhammadiyah's 47th Congress and Islam Berkemajuan. Studia Islamika. 22(2): 377-386. https://doi.org/10.15408/sdi.v22i2.1978

Ammar, J. \& Xu, S. 2017. When Jihadi Ideology Meets Social Media. Cham, Switzerland: Palgrave Macmillan. DOI 10.1007/978-3-319-60116-8_1.

Amrizal, A. 2018. Melacak jejak-jejak sufistik dalam pandangan hidup orang-orang Melayu. Madania: Jurnal Ilmu-Ilmu Keislaman. 3(2): 123-143.

Arifianto, A. R. 2017. Islam Nusantara \& its critics: the rise of NU's young clerics. RSIS Commentary, https://www.rsis.edu.sg/wp-ontent/uploads/2017/01/C017018.pdf. Retrieved on 25 April 2017 at 20.31 Western Indonesian time zone.

Auster, L. 2005. The search for moderate Islam. FrontPageMagazine.com http://www.clhrf.com/islamic\%20issues/moderate.islam28.1.05.htm. Retrieved on 26 May 2018 at 09.12 Western Indonesian time zone.

Azra, A. 1990. Jaringan Ulama Timur Tengah dan Kepulauan Nusantara Abad XVII dan XVIII (Cet. ke 2). Bandung: Penerbit Mizan.

Azra, A. 2015. Islam Indonesia berkelanjutan. Opini Kompas. Article published On 3 August 2015 at https://nasional.kompas.com/read/2015/08/03/15000031/Islam.Indonesia.Berkelanjut an?page=all. Retrieved on 29 January 2018 at 17.18 Western Indonesian time zone. 
Bakri, S. 2014. Pendekatan-pendekatan dalam Islamic studies. Dinika: Journal of Islamic Studies. 12(1): 7-16.

Bruinessen, M. V. 1992. Tarekat Naqsyabandiyah di Indonesia. Bandung: Mizan.

Burhanudin, J., \& van Dijk, K. (Eds.). 2013. Islam in Indonesia: Contrasting Images and Interpretations. Amsterdam: Amsterdam University Press.

Campbel, T. \& Hardiman, F. B. 1994. Tujuh Teori Sosial. Jakarta: Kanisius.

Echols, J. M. \& Shadily, H. 1996. Kamus Inggris-Indonesia. Jakarta: Gramedia.

Elmansyah, E., bin Haji Masri, M., \& Bujang, S. 2019. Sufism and Millennial generation movements in modern Nusantara. Al-Albab. 8(1): 43 - 56. doi:https://doi.org/10.24260/alalbab.v8i1.1272

el-Fadl, K. A. 2005. The Great Theft: Wrestling Islam from the Extremist. New York: HarperCollins Publisher2.

Esposito, J. L. (2005). Moderate Muslims: A Mainstream of Modernists, Islamists, Conservatives, and Traditionalists. American Journal of Islam and Society, 22(3), 11-20. https://doi.org/10.35632/ajiss.v22i3.465

Esposito, J. L., \& Mogahed, D. 2006. What makes a Muslim radical? Foreign Policy. https://foreignpolicy.com/2006/11/16/what-makes-a-muslim-radical/ article published on November 16, 2006, 12:00 AM. Retrieved on 29 July 2019 at 17.12 Western Indonesian time zone.

Fachrudin, A. A. 2015. The face of Islam Nusantara. The Jakarta Post. https://www.thejakartapost.com/news/2015/07/24/the-face-islam-nusantara.html. Retrieved on 14 August 2019 at 09.10 Western Indonesian time zone.

Faiz, F. 2014. Front Pembela Islam: antara kekerasan dan kematangan beragama. Kalam. 8(2): 347366. https://doi.org/10.24042/klm.v8i2.226

Fathun, L. M. 2016. ISIS Dalam diskursus pembentukan negara bangsa. Thaqafiyyat: Jurnal Bahasa, Peradaban dan Informasi Islam. 16(2): 219-238.

Frusetta, J. 2014. Balkan Genocides: holocaust and ethnic cleansing in the twentieth century. Holocaust and Genocide Studies. 28(3): 535-537. https://doi.org/10.1093/hgs/dcu047

Fuad, A. J. 2015. Infiltrasi Salafi Wahabi pada buku teks di madrasah dan respons warga Nahdliyin. Maraji: Jurnal Ilmu Keislaman, 1(2): 361-392. https://doi.org/10.36835/maraji.v1i2.23

G.A, D. A., Nasih, A. M., \& Legawa, I. W. 2015. Hindu - Islam harmonization in Bali case study on the graves of Raden Amangkuningrat and Ratu Ayu Agung Rai. Research on Humanities and Social Sciences. 5(24): 34-40-40.

Gibb, H. A. R. 1945. Modern Trends in Islam. Chicago: Chicago University Press.

Hakiki, K. 2018. Insan Kamil dalam Perspektif Syaikh Abd al-Karim al-Jili. Wawasan: Jurnal Ilmiah Agama dan Sosial Budaya, 3(2), 175-186. doi:https://doi.org/10.15575/jw.v3i2.2287

Hamka. 1996. Tasawuf Modern. Jakarta: Pustaka Panji Mas.

Hanapi, M. S. 2014. The wasatiyyah (moderation) concept in Islamic epistemology: a case study of its implementation in Malaysia. International Journal of Humanities and Social Science. 4(9): 5162.

Hefner, R. W. 2002. Global violence and Indonesian Muslim politics. American Anthropologist. 104(3): 754-765. https://doi.org/10.1525/aa.2002.104.3.754

Helmy, M. 2011. Akar-akar transnasionalisme Islam Hizbut Tahrir Indonesia (HTI). Islamica: Jurnal Studi Keislaman. 6(1): 1 - 13.

Hornby, A. S. 1983. Oxford Advanced Learner's Dictionary of Current English. Oxford: Oxford University Press.

Ismardi, \& Arisman. 2014. Meredam Konflik dalam upaya harmonisasi antar umat beragama. Toleransi: Media Ilmiah Komunikasi Umat Beragama. 6(2): 200-222. https://doi.org/10.24014/trs.v6i2.907. 
Jubba, H., Pabbajah, M., Prasodjo, Z.H., Qodir, Z. 2019. The future relations between the majority and minority religious groups, viewed from Indonesian contemporary perspective: a case study of the coexistence of Muslims and the Towani Tolotang in Amparita, South Sulawesi. International Journal of Islamic Thought. 16:13-24. https://doi.org/10.24035/ijit.16.2019.002.

Kasdi, A. 2019. Wasathiyyah Islam as the Road to Moderatism in Indonesia. Al-Albab, 8(2), 179 - 192. doi:https://doi.org/10.24260/alalbab.v8i2.1356.

Kamaruzzaman, B. A. 2002. Islam Historis: Dinamika Studi Islam di Indonesia. Yogyakarta: Galang Press.

Karim, A. 2007. Sejarah Pemikiran dan Peradaban Islam. Yogyakarta: Pustaka Book Publisher.

Khamdan, M. 2016. Pengembangan Nasionalisme Keagamaan Sebagai Strategi Penanganan Potensi Radikalisme Islam Transnasional. Addin. 10(1): 207- 231

https://doi.org/10.21043/addin.v10i1.1135.

Lai, B. 2006. An empirical examination of religion and conflict in the Middle East, 1950-1992. Foreign Policy Analysis. 2(1): 21-36. https://doi.org/10.1111/j.1743-8594.2005.00018.x

Luthfi, K. M. 2016. Islam Nusantara: Relasi Islam dan budaya lokal. Shahih: Journal of Islamicate Multidisciplinary. 1(1): 1-12.

Mazuki, A. A. M., Mujani, W. K., Aziz, A., \& Rozali, E. A. 2013. Application of the wasatiyyah concept to the formation of the Medina Charter. International Journal of West Asian Studies. 5(2): 1-15.

Misrawi, Z. 2010. Pandangan Muslim Moderat: Toleransi, Terorisme dan Oase Perdamaian. Jakarta: PT. Kompas Gramedia.

Muhayya, A. 2001. Peranan tasawuf dalam menanggulangi krisis spiritual. In, M. Am. Syukur \& A. Muhayya (Eds.). Tasawuf dan Krisis. Yogyakarta: Pustaka Pelajar. p: 26-35.

Murod, A. C. 2011. Nasionalisme dalam perspektif Islam. Jurnal Sajarah Citra Lekha. 16(2):45-57.

Nasr, S. H. 1996. Ideals and Realities of Islam. London: George Allen \& Unwin Ltd.

Noer, D. 1973. The Modernist Muslim Movement in Indonesia. 1900-1942. Oxford: Oxford University Press.

Nurhisam, L. 2016. Islam Nusantara: A midle way? Shahih: Journal of Islamicate Multidisciplinary. 1(2): 167-177.

Nursyam. 2009. Tantangan Multikulturalisme Indonesia: Dari Radikalisme Menuju Kebangsaan. Yogyakarta: Kanisius.

Pipes, D. 2005. Finding Moderate Muslims-More Questions. www.danielspipes.org. http://www.danielpipes.org/blog/2005/10/finding-moderate-muslims-more-questions, Oct 5, 2005. Retrieved on 17 June 2018 at 11.10 Western Indonesian time zone.

Rosyidi, A. W. 2012. Doa dalam tradisi Islam Jawa. El Harakah Jurnal Budaya Islam. 14(1): 88-100. https://doi.org/10.18860/el.v0i0.2199.

Sahal, A. 2015. Islam Nusantara dari Ushul Fiqh hingga Paham Kebangsaan. Bandung: Mizan Pustaka.

Shihab, A. 2001. Islam Sufistik: Islam Pertama dan Pengaruhnya hingga Kini di Indonesia. Bandung: Mizan.

Shihab, M. Q., 2007. Secercah Cahaya Ilahi: Hidup Bersama Al-Qur'an. Bandung: Mizan.

Siroj, S. A. 2009. Tasawuf Sebagai Kritik Sosial: Mengedepankan Islam Sebagai Inspirasi, Bukan Aspirasi. Bandung: Mizan.

Sugiharto, I. B. 1996. Postmodernisme Tantangan Bagi Filsafat. Yogyakarta: Kanisius.

Syukur, A. 1999. Menggugat Tasawuf: Sufisme dan Tanggungjawab Sosial Abad 21. Yogyakarta: Pustaka Pelajar.

Tabik, A. 2016. Harmonisasi kerukunan antar etnis dan penganut agama di Lasem. Jurnal Ilmu Aqidah dan Studi Keagamaan. 4(1): 36-49.

Zakarya. A.R. 2017. Islam Moderat, Islam Gaya Barat. Www.voa-islam.com. http://www.voaislam.com/read/world-analysis/2017/04/25/50232. Retrieved on Tuesday, 27 Rabiul Awwal 1442 H / 25 April 2017 at 23:38 Western of Indonesian time zone. 